\title{
How Careers Advice and Guidance can Facilitate Career Development in TVET Graduates: The case in Nigeria
}

Ugochukwu Chinonso Okolie; Chinyere Augusta Nwajiuba; Michael Olayinka Binuomote; Catherine U. Osuji; Onajite G. O., Paul Agu Igwe (2020) How Careers Advice and Guidance can Facilitate Career Development in TVET Graduates: The case in Nigeria. The Australian Journal of Career Development. Accepted: 07-Mar-2020

\section{Contributing Authors}

\section{Ugochukwu Chinonso Okolie}

Alex-Ekwueme Federal University, Ndufu-Alike, Ikwo, Nigeria. nonyeck@gmail.com

\section{Chinyere Augusta Nwajiuba, PhD}

Alex Ekwueme Federal University, Ndufu Alike Ikwo, Nigeria. caanwajiuba@gmail.com

\section{Michael Olayinka Binuomote, PhD}

Alex Ekwueme Federal University, Ndufu-Alike, Ikwo, Nigeria. binuomotemichealolayinka@gmail.com

\section{Catherine U. Osuji, PhD}

Rivers State University, Port-Harcourt, Nigeria.

kathyosuji@yahoo.com

\section{Onajite G. O., PhD}

Ekiti State University, Ado Ekiti, N igeria.

onajitego@gmail.com

\section{Paul Agu Igwe, PhD}

University of Lincoln, UK.

pigwe@lincoln.ac.uk

\begin{abstract}
This study examined the current state of careers advice, guidance, and counselling (CAGC) services and programs in the technical, vocational education, and training (TVET) system of Nigerian higher education institutions (HEIs). This was to determine how well current CAGC services and programs foster students' career development, aspirations, and choices. Fortyeight participants, who were members of the Nigerian National Board for Technical Education (8 participants), guidance counsellors (6), university TVET teachers (18), career experts from the National Directorate of Employment (7), and newly employed TVET graduates (9), volunteered for the study. A purposeful sampling procedure was adopted to recruit participants. Data were collected using a semi-structured interview approach, and we employed a thematic design for the coding and analysis of the transcribed data. The study found no CAGC services and programs in the TVET system. It is recommended, therefore, that TVET systems should
\end{abstract}


focus on providing career development enhanced learning rather than schooling only by revising the curriculum to include programs and activities that promote CAGC activities and programs.

Keywords: Career Guidance, Career Development, Counselling, Technical \& Vocational Education, TVET

\section{Introduction}

Nigeria is a major regional player in Sub-Saharan Africa with a population of approximately 197 million; accounting for about $47 \%$ of West Africa's population it has the largest population of youth in the world (World Bank, 2019). As a growing economy, Nigeria requires skilled TVET graduates who can fill the ever-growing demands of the labour market. Nigerian technical, vocational education, and training (TVET) policy, as presented in the National Policy on Education of the Federal Republic of Nigeria (2013), focuses on fostering learners' development of saleable skills, awareness, and attitudes for work. TVET is offered by higher education institutions (HEIs) as a fully accredited course of study. It is regulated by two major regulatory bodies: the National Board for Technical Education, which regulates the programs in polytechnics and colleges of education (technical), and the Nigerian Universities Commission, which regulates programs in universities. TVET departments of HEIs admit students to study from undergraduate to $\mathrm{PhD}$ level. The areas of specialization include electrical/electronic technology, mechanical technology, building/woodwork technology, business education and secretarial studies, home economics and hotel management, and agricultural education.

Nigerian HEIs have different names for TVET, such as technology and vocational education, industrial and technical education, and vocational and technical education (Okolie, 2014; Okolie, Igwe, \& Elom, 2019). We adopt UNESCO's definition of TVET as "education, training and skills development relating to a wide range of occupational fields, production, services, and livelihoods (which include) work-based learning and continuing training and professional development which may lead to qualifications" (UNESCO, 2015, p. 45). TVET can be formal (e.g., provided by an educational or training institution and leading to certification), non-formal (e.g., training occurring outside the formal system), or informal (e.g., learning resulting from daily life activities related to work, family, or leisure; UNESCO, 2012).

There is a growing importance of TVET, particularly in developing countries due to its role in linking education and employment (Rawkins, 2018). TVET is an education program that aims to prepare learners for entry into employment in their chosen careers and meet the labour market needs of a nation (Federal Republic of Nigeria, 2013). It has been identified as a major provider of skills development in many countries and has helped to address the challenges of youth employment by enhancing learners' employability (Alagaraja \& Arthur-Mensah, 2013).

\section{Purpose of Current Study}

Previous studies have reported that Nigerian TVET graduates are not adequately equipped with the saleable skills required by employers (Mohammed \& Ismail, 2015; Musa, 2010; Nwankwo, Obeta, \& Nwaogbe, 2013). Studies have also linked Nigerian TVET graduate unemployment to poor career preparation of graduates (Okolie, Nwosu, \& Mlanga, 2019; Okunuga \& Ajeyalemi, 2018). This reflects poorly on the Nigerian HEIs' implementation of extracurricular activities and career development programs, such as work-placements, career fairs, 
CV preparation workshops, career networking, career mentoring, coaching on interview techniques, and support with job applications, which can foster students' career development, aspirations, and choices (Ojimba, 2012; Okolie, Nwosu \& Mlanga, 2019; Oluwale, Jegede, \& Olamade, 2013; Usman \& Tyabo, 2013). While possible strategies for improvements have been recommended (Eze, 2013; Okolie, Igwe, \& Elom, 2019; Oluwale, Jegede, \& Olamade, 2013), little is known about how adequately careers advice, guidance, and counselling (CAGC) services and programs foster TVET students' career development, aspirations, and choices in Nigerian HEIs.

While there are studies on guidance and counselling programs in the primary and secondary school systems in Nigeria (Akpan, 2010; Aluede, Afen-Akpaida, \& Adomeh, 2004; Aluede, 2000; Efeturi, 2015; Modo, Sanni, Uwah, \& Mogbo, 2013; Mogbo, Obumneke-Okeke, \& Anyachebelu, 2011), there is little formal evaluation of CAGC in the TVET system of HEIs. This lack of information about CAGC services and programs means that it is difficult to identify which CAGC services and programs have been effective for the career development, aspirations, and choices of TVET graduates. It is against this backdrop that this study examines the current state of CAGC services and programs in the TVET system of Nigerian HEIs. The study is guided by the following research questions:

RQ1: What is the current state of CAGC services in the TVET system of Nigerian HEIs?

RQ2: How can the TVET program of Nigerian HEIs focus on providing career development enhanced learning rather than schooling only to foster students' career development, aspirations, and choices?

The study is positioned in the career development debate and the transition of human capital from the HEI sector into the graduate labour market. The study aims to advance knowledge of the CAGC in the Nigerian TVET context and contribute to discussions that can lead to policies directed towards improving the TVET system of Nigerian HEIs, as well as those of other developing countries (Hunkin, 2018; Page, Trudgett, \& Bodkin-Andrews, 2018).

\section{Literature Review}

Due to the demand for a skilled workforce in Nigeria, several reforms have taken place in the last decades in the HEI system. The government has encouraged TVET programs in all HEIs, and many have moved simultaneously on two interrelated fronts: they have found ways to improve the quality and relevance of the programs they offer, especially in the area of TVET, and have improved technology and begun to provide quality infrastructure for teaching (Iruonagbe, Imhonopi, \& Egharevba, 2015). However, despite these improvements, there is evidence that HEI students have difficulty determining appropriate career paths, which might negatively affect the employability, career aspirations, and choices of the graduates (Pitan 2016a \& 2017).

The Nigerian TVET policy context has been characterized by two complementary themes. The first is the drive for greater social inclusion through developing knowledge, attitudes, and practical skills relevant for gainful employment or self-employment. The second is greater support for students at risk of exclusion; thus, increasing participation in lifelong learning and reducing youth unemployment and poverty (Okolie, Igwe, \& Elom, 2019). Given the learning, social, and economic benefits of TVET, CAGC services and programs can play a significant role in promoting the TVET policy as explained in the national policy on education of the Federal Republic of Nigeria. 
Student career aspirations and choices might be influenced by multiple factors, including personality, interests, self-concept, cultural identity, globalization, socialization, role models, parental influence, social support, and available resources, such as course information and adequate finances (Reddya \& Rajaram, 2015). The provision of CAGC is necessary to foster student understanding of their career aspirations and what they can do after graduation. This study adopts the Organisation for Economic Co-operation and Development's (OECD, 2019, p. 97) definition of career guidance and counselling, as "the services and activities intended to assist individuals, of any age and at any point throughout their lives, to make educational, training and occupational choices and to manage their careers".

As Christie (2016) explained, CAGC services and programs include a broad range of activities, such as one-to-one advice and guidance within a portfolio of activities generally managed by a central careers service. Such services can be found in schools, universities and colleges, training institutions, public employment services, the workplace, the voluntary or community sector, and in the private sector. CAGC activities include career information provision, assessment and self-assessment tools, counselling interviews, and career education programs, "taster" programs that allow job-seekers to sample options, job search, and transition services. Due to the importance of CAGC for graduate employability, there have been several studies that examined the relationships between career education and graduate career aspirations and choices in multiple contexts (e.g., Bimrose \& Hearne, 2012; McKenzie, Coldwell-Neilson \& Palmer, 2017; Reddya \& Rajaram, 2015).

Solem, Kollasch, and Lee (2013) found that there were many organizational and businessoriented skills that employers value, but these were not commonly taught in graduate curricula in the USA HEI system. McKenzie, Coldwell-Neilson, and Palmer's (2017) study on "understanding the career aspirations and skill development action plans of Information Technology students in Australian HE(I)" found variability in students' short-term aspirations and a lack of understanding regarding effective actions to achieve their career goals, highlighting issues with setting realistic expectations. In Nigeria, Pitan and Atiku (2017) examined "students' employability through career guidance activities offered at selected universities", finding a positive influence for career guidance activities on student employability. Pitan and Atiku (2017, p. 10) also found that "self-awareness and opportunity awareness have the greatest influence on students' employability, followed by decision-making skills, and then transition learning skills". Pitan (2016b) investigated employability development opportunities as measures of students' enhanced employability in Nigeria and found a significant positive relationship between these and HEI students' enhanced employability.

\section{Theoretical Underpinning}

The dominance of human capital theory (HCT) in the economics of education literature is matched by its authority in the public and policy domains (Marginson, 2019). This study adopts HCT, which explains the connections between education, human, and social development (Schultz, 1959). In the foundational narrative of HCT, education drives the marginal productivity of labour, and this, in turn, drives earnings: this is now a common policy assumption (Marginson, 2019). HCT offers a theoretical foundation for an understanding of a personal approach to career success (Ballout, 2007). HCT suggests that a personal investment in education or training (a human capital attribute) is expected to show a higher level of work performance and then result in higher organizational rewards. 
According to Becker (1964), an individual's career progression and success are contingent upon the quantity and quality of human assets one brings to the labour market. As Ballout (2007, p. 743) stated: "human capital factors influence the performance of employees, greater personal attributes would enable them to better perform their job, and their pay should increase accordingly to compensate them for the additional amount of human capital required by their job". The literature shows that human capital variables have a significant impact on career success and the number of promotions (Berntson, Sverke \& Marklund, 2006; Savickas, 2011). Ballout (2007) emphasized that career success has emerged as an important concern for education stakeholders due to the demonstrated links between career success and many individual and organizational variables. Ballout (2007) further explained that career success was assumed to be a function of human, motivational, and organization-specific variables that influence career success.

A related dimension is the causal impact of education on democracy. Glaeser, Ponzetto, and Shleiferp (2007, p. 78) noted that "the uneducated (person) or the (person) with limited education is a different political actor from the (person) who has achieved a higher level of education". These relationships affirm that formal education is construed as productive investment in fostering human capital, which the proponents of the theory have considered to be equal to, or even more worthwhile than, physical capital (Pitan, 2017). Also, Pitan (2017) noted that HCT explains that the main determinant of the demand for higher education is the expectation of greater earnings over the individual's lifetime; as such, earnings are necessary to compensate for the higher costs associated it.

\section{Methodology}

This study, conducted in Nigeria, adopts a qualitative research design intended to capture comprehensive and rich information by offering participants an opportunity to speak freely about their experiences regarding the subject of study (Ary, Jacobs, \& Sorenson, 2010; Creswell, 2007). Participants were identified and selected from six Nigerian public universities (that offer TVET degrees), the office of the National Board for Technical Education, and the office of the National Directorate of Employment. Also, newly employed TVET graduates identified in their places of work were invited to participate. A public university from each of the six geo-political zones of Nigeria was selected. The motive for selecting only the public universities was that they employ more qualified TVET teachers and admit more TVET students. The National Directorate of Employment and the National Board for Technical Education have offices both in the Northern and Southern parts of Nigeria, which made the process of identifying their staff easier.

Purposeful sampling procedure, which is widely adopted in qualitative research for identifying and selecting individuals or groups that have shown considerable knowledge about an issue or have significant experiences as to offer rich information, was adopted to recruit participants (Patton, 2002). Prospective participants were informed of the research aim, and were given research consent forms to complete and return to the lead researcher via email should they willingly wish to participate in the study. The research consent form was designed to harness a short profile of the participants, although they were assured of anonymity and their right to decline their interest in the study.

Six email reminders were sent to the prospective participants within three months, and this process identified a total of 48 participants drawn from senior staff of the National Board for Technical Education ( $n=8 ; 6$ male; aged 39 to 59 years), guidance counsellors at the six sampled public universities ( $n=6 ; 1$ male; 41 to 57 years), TVET teachers (lecturers) from the 
same six federal universities ( $n=18 ; 13$ male; 39 to 60 years), career experts at the National Directorate of Employment ( $n=7 ; 5$ male; 37 to 51 years) and newly employed TVET graduates ( $n=9 ; 7$ male $=7 ; 28$ to 38 years). Except for the newly employed TVET graduates, all participants had $>10$ years of work experience in their respective organizations. The newly employed TVET graduates had two years of work experience in their places of work, but they were expected to offer substantial information regarding the subject of study having graduated from the TVET program and secured employment in the labour market. Following the assumptions of Guest, Bunce, and Johnson (2006), the number of participants was considered appropriate for this study.

\section{Data Collection and Analysis}

Data were collected using semi-structured interviews. Participants were interviewed face-toface in their chosen convenient venues and times. The interviews began with general questions to make the interviewees comfortable and familiarize them with the subject of study (Lingard $\&$ Kennedy, 2010). Sample questions were: "Please can you tell me, what do you know about careers advice, guidance, and counselling? What is the current state of career advice, guidance and counselling programs at your university? How has your institution provided career advice, guidance, and counselling to students to foster students' career development, aspirations, and choices?". Data collection occurred from October 2018 to March 2019, with interviews taking 35 to 56 minutes depending on participants' ability to express themselves. All interviews were recorded using an electronic device with the participants' consent, and the recorded data were transcribed verbatim.

The data were coded using NVivo V12 plus. Three different coders with no prior knowledge of the study were employed to code the data separately to ensure intercoder reliability (Gibbert Ruigrok, \& Wicki, 2008; Floersch, Longhofer, Kranke, \& Townsend, 2010). For the thematic analysis, the steps prescribed by Braun and Clarke (2006), which include, (a) becoming familiar with the data, (b) assigning preliminary codes to the data in order to describe the content, (c) searching for patterns or themes in the codes across the interviews, (d) reviewing the themes, (e) defining and naming themes, and (f) producing the report, were adopted. To ensure anonymity, participants' data were coded: participants from the National Board for Technical Education were coded as SS-NBTE, guidance counsellors as GC-NU, TVET teachers as TVETT, career experts at the National Directorate of Employment as CE-NDE, and newly employed TVET graduates as NE-TG.

\section{Findings}

From the thematic analysis, two dominant themes were identified based on the research questions. These themes were the current state of CAGC services and curriculum design, and effective HEI and industry linkages.

\section{The current state of CAGC services}

Participants described the current situation of CAGC services and programs. They acknowledged that every HEI in Nigeria had a central counselling unit or centre, which offered general guidance and counselling services to students and staff; however, these counselling centres did not specifically offer CAGC services to students, and they were not specifically established to foster TVET students' career development, aspirations, and choices. Participants also confirmed that no university department (TVET inclusive) had a CAGC centre or offered special CAGC services and programs to students to foster career development, aspirations, and choices: 
My university has a central counselling or advice centre where students go to receive counselling on depression, coping with studies, relationships, etc... but, I do not know about any centre specifically built either for TVET students or others to receive careers advice, guidance, and counselling (GC-NU - 2).

The guidance counsellors noted that there was a distinction between general counselling services and CAGC services. They pointed out that the majority of guidance counsellors who managed the HEIs' central counselling centres could not provide assistance beyond the general counselling services to TVET students, as they were not professional career development experts. This suggests that TVET students might not have sufficient access to quality CAGC services from the central guidance counselling centres:

...we must, however, draw a thick line between offering general guidance and counselling services and career advice, guidance, and counselling services. I am convinced that the knowledge and expertise of the university counsellors, and even the lecturers, may not offer much-needed professional career advice, guidance, and counselling that our students need to develop career-wise... universities have to establish and specifically build career development centres in TVET and other departments (GC-NU - 1).

This participants' report indicates the need for establishing functional CAGC centres in TVET departments and employing professional career development experts to manage such centres. This could help TVET students seek one-on-one career development-related answers from experts, participate in career development activities, understand their career pathways, and obtain first-hand career-related information to clarify their aspirations and choices:

Even though we try to integrate many things into the university central counselling centre, I must state clearly that our role as counsellors includes counselling students on... overcoming social and academic problems, identifying positive personality traits, recognizing academic interests, values, abilities, excelling in one's academic pursuits, etcetera... so, our services don't specifically foster students' career development, aspirations, and choices (GC-NU - 5).

This participant's narrative supports the idea that, in addition to the central guidance counselling centres of HEIs, TVET departments could benefit from establishing a functional CAGC centre. The centre could be responsible for providing TVET students with career development and employability services, relevant job information, first-hand information on labour market trends and demand, coaching students on CV writing and interview techniques, organizing career development seminars and workshops, among other services. Participants also acknowledged efforts of HEIs towards improving students' career development and employability, but pointed out that the efforts were not adequate. For example, HEIs conduct career development and skills acquisition programs through the 3-6 month student industrial work experience scheme (SIWES), but the effectiveness of this program has not been ascertained:

Every year, we send our students to the 6-month industrial work-placement program, referred to as IT or SIWES. The program exposes our students to skills acquisition and career development outside the university environment. However, we are yet to ascertain the program's successes in fostering students' career development, aspirations, and choices (TVETT-4). 
The majority of participants pointed out that even though TVET departments made use of the SIWES program, its impact on students' career development, aspirations, and choices might not be as important as the services offered via CAGC, although this assumption needs to be tested:

One major challenge with SIWES is that it is not controlled at the department level; rather at the university level... so, students are mostly sent to industries that are not related to their field of studies, which affects them negatively. In most cases, students are sent to industries that are no longer functional, since the students look for industries by themselves. Secondly, due to poor industry and university supervision during the program, many students do not fully participate in the six months SIWES program... I feel that SIWES cannot effectively foster students' career development, aspirations, and choices... but, careers advice, guidance, and counselling centres, (which could be) domiciled in the TVET departments of all Nigerian universities with professional career development experts, (could) (TVETT-07).

Acknowledging the efforts of HEIs to ensure that students understand their career pathways, improve their employability skills, and become work-ready, participants acknowledged that some courses aimed to improve TVET graduates' careers and employability. However, such courses were not designed to offer labour market-relevant and modern career-related information; rather the courses were designed to teach career development theories, which in most cases are not put into practice:

Although there were some career development courses we took during my undergraduate days, the ratio of a lecturer to students was about 1:150. Moreover, students were more interested in passing the course written examinations than focusing on the career implications of the courses (NE-TGs-3).

Participants emphasised establishing CAGC centres in every TVET system. While HEIs make efforts to foster students' career development and employability through SIWES and other faculty-wide courses, which have been acknowledged in this study, participants felt that CAGC services and programs might have more positive impacts on students' career development, aspirations, and choices.

\section{Curriculum design, and effective HEI and Industry Linkages}

While participants explained the current state of CAGC services and programs in the TVET system, they offered suggestions on how the TVET programs can focus on providing career development enhanced learning rather than schooling to foster students' career development, aspirations, and choices. During interviews, some of the discussions also centred on TVET curriculum design. Many participants noted that aside from establishing CAGC services centres in all the TVET departments, the current TVET curriculum do not provide adequate room for programs and activities that can foster students' career development, aspirations, and choices:

Our TVET curriculum has been designed to support more theoretical learning and faceto-face lecture system, which has made practical knowledge and career development activities mostly ignored (TVETT -3). 
This participant's expression illustrates the important role that a well-structured curriculum can play in helping graduates' career development and aspirations. For example, participants pointed out that TVET curriculum revision to include career development programs and activities can enhance skills mastery as students can construct learning on their own, and boost their chances of employment:

TVET students can understand their career pathways, work on their career aspirations and choices, and develop saleable skills to compete with the world of work if the TVET curriculum can be redesigned to include innovative teaching and learning approaches like problem-based learning, self-directed learning, collaborative learning, among others (SS-NBTE- 3).

This expression reflects the conclusion from the literature review (Mohammed \& Ismail, 2015; Musa, 2010; Nwankwo, Obeta, \& Nwaogbe, 2013) that redesigning the TVET curriculum to include innovative teaching techniques can help to reduce over-dependence on the traditional teaching methods. Participants also suggested the use of active learning techniques to effectively engage students in meaningful learning:

In addition to establishing a careers advice, guidance and counselling centre in our department, I feel that TVET teachers can adopt more effective learning approaches to boost students' interests in achieving their career aspirations (CE-NDE -3).

Participants suggested that the TVET system can focus on providing career development services to students by training the teachers on CAGC-related services. For example, training can focus on effective classroom learning that promotes labour market-relevant skills development, experiential learning, teacher-to-student careers advice, careers information sources, among others:

...looking at the current situations in the TVET system...I am convinced that we need to take the same measures that advanced countries like the UK, Australia, Germany, and the Netherlands took to reform their TVET systems...we should review and revalidate all TVET courses... remove the courses that have no relevance for modernday society and labour market (SS-NBTE -1).

Many participants agreed that some of the TVET courses are not labour-market relevant. Participants suggested that reviewing and revalidating the TVET courses can help to include labour market-driven courses in the curriculum, instead of teaching based on an outdated curriculum that is not regularly reviewed and validated.

Reflecting on how else the TVET system can focus on providing career development enhanced learning to foster students' career development, aspirations, and choices, participants recommended building effective linkages between the TVET system and industry:

Like I said...the TVET system and industry can jointly redesign industry-focused courses, modules, or career development enhanced activities to support students (CENDE -4).

This participant pointed out an important strategy for involving industry in TVET learning. Another participant advised: 
As TVET teachers, we must respond to the ever-increasing emphasis on work-place learning, work-based learning, and problem-based learning that allow students to experience deep learning and skills mastery, support students in making informed decisions about future careers. A strong link between industry and TVET system is essential (TVETT-9).

This participant's statement explained the role the TVET teachers can play in providing career development enhanced learning to foster students' career development, aspirations, and choices. Participants pointed out that students can benefit from industry partnerships in TVET learning by receiving up-to-date information and counselling on employment trends:

Industry involvement in TVET learning can help to establish quality policies and mechanisms for graduating TVET students based on skills mastery instead of written theses (SS-NBTE -3).

Drawing on participants' views, there is an indication that CAGC services and programs can foster TVET students' development of labour market-relevant skills and knowledge. It is, therefore, important that the TVET system should re-examine the curriculum for inclusion of CAGC activities to enable students to maximize the return on investment for social and economic benefits (in line with the human capital theory). Participants also suggested changing the orientation that the TVET graduate degree is specifically for employment in the public service or white-collar jobs instead of industry. Such orientation can promote skills development and career development concepts. Many participants recommended initiating quality reforms in the TVET system to reflect global best practices. Such reforms can focus on TVET students' graduation processes, courses relevance to industry, recruitment of teaching staff, admitting qualified students into the TVET program, evaluation of TVET employability outcomes, etcetera.

\section{Discussion}

Drawing on these two key themes, it can be seen that participants placed a high value on establishing CAGC services centre in every TVET system, establishing effective linkages between the TVET system and industry, and promoting student-centred learning approaches that can encourage career learning and development. The participants suggested that the TVET curriculum should be revised to include up-to-date career development enhanced activities and programs to help students understand and pursue their career goals (in line with Okolie, Igwe, \& Elom, 2019; Okolie, Nwosu, \& Mlanga, 2019).

The study found that there were no CAGC services and programs in the TVET system. Although many HEIs have central counselling centres that provide services for students' mental health issues, examination-related challenges, managing behaviour, and academic performance, these services did not effectively foster students' career development, aspirations, and choices. Also, participants confirmed that the counsellors managing the HEIs' central counselling centres were not professionally trained to provide significant career development support. Therefore, the distinction between the HEIs' counsellors' roles and those of the CAGC experts were drawn (in agreement with Eyo, Joshua, \& Esuong, 2010; Lunenburg, 2010).

Participants linked graduates' low career aspirations to lack of access to CAGC services and programs. An interesting finding was that by establishing CAGC services centres, and employing career experts to run the centres, they also might help graduates with areas like graduate placements, career fairs, further study opportunities, CV and job interview 
preparation, networking with peers, accessing careers mentoring opportunities, and job application supports, which the HEIs' central counselling centres cannot offer (in line with Mutie \& Ndambuki, 2011).

The findings of this study revealed that the Nigerian TVET system could focus on providing career development enhanced learning, rather than schooling only, by revising and redesigning the TVET curriculum to include programs and activities that promoted CAGC activities and programs. The findings indicated that revising the TVET curriculum to provide labour marketrelevant skills to students could enhance graduates' transition to industry. Arguably, awareness of the broader world of work should be established early in students' school experience, and this would require integration of CAGC activities and programs in the TVET curriculum (in line with Foskett, 2004). These findings have implications for pedagogical approaches and contribute to the ongoing political, economic, and social debate on improving the Nigerian TVET system (in line with Emeh, Nwanguma, \& Abaroh, 2012).

The findings also argue for the importance of adopting innovative teaching approaches for TVET teaching and learning, such as problem-based learning, self-directed learning, workbased learning, and collaborative learning approaches that promote careers learning and deep learning. This would entail modification of the existing TVET curriculum to provide a more diverse range of courses that can accommodate students' diverse career interests. It also might mean that some/every TVET course might contain less academic content and be more practical and experiential.

Complementing this finding, Okolie, Nwosu, and Mlanga (2019) noted that the disparity between industry expectations and HE provision could result from ineffective teaching techniques. Teachers' poor teaching techniques can negatively affect students' career development, aspirations, and choices (Hack-Polay, Igwe \& Okolie, 2020; Okolie, Igwe \& Elom, 2019). However, it is important to note that adopting innovative teaching techniques in the TVET system would mostly depend on teachers' competencies, which could be improved through continuous professional development training (Ansah \& Kissi, 2013; Okunuga \& Ajeyalemi, 2018).

\section{Conclusion}

The findings indicated that building strong linkages between the TVET system and industry might be an efficient strategy for fostering students' career development, aspirations, and choices, and building effective linkages between TVET and industry might have the added benefit of facilitating students' transition to industry. The findings also highlight for TVET practitioners, policymakers, industry and TVET curriculum developers how CAGC services and programs in the TVET system might help graduates to develop labour-market relevant skills and knowledge for employment. The study serves as a starting point for other researchers, and while it focused on Nigerian HE, the results will be relevant to other developing countries.

\section{Limitations and Implications for Policy and Practice}

Despite the contribution of this study in extending the TVET literature in the Nigerian context, there are some limitations. The study did not examine the possible challenges that could emerge from establishing CAGC services centres in all TVET departments and from building CAGC activities and programs into the TVET curriculum. The study also did not address the steps that could be taken towards redesigning the TVET curriculum in order to focus on career development enhanced learning as this was beyond the scope of the study. Last, and for the 
same reason, the study was not able to explain how the TVET system might identify potential industries for effective linkages. Further studies need to focus on addressing these limitations.

\section{References}

Akpan, N. U. (2010). The challenges of guidance and counselling service in primary schools in Akwa, Nigeria. Ibom Journal of Counselling, 1(1), 97-106.

Alagaraja, M., \& Arthur-Mensah, N. (2013). Exploring technical vocational education and training systems in emerging markets: A case study on Ghana. European Journal of Training and Education, 37(9), 835-850. doi:10.1108/EJTD-04-2013-0037

Aluede, O. O. (2000). The realities of guidance and counselling in Nigeria secondary schools: Issues and benefits. Guidance and Counselling, 15(2), 22-26.

Aluede, O., Afen-Akpaida, J. E., \& Adomeh, I. O. (2004). Some thoughts about the future of guidance and counselling in Nigeria schools. Education, 125(2), 296-305.

Ansah, S. K. \& Kissi, E. (2013). Technical and vocational education and training in Ghana: A tool for skill acquisition and industrial development, Journal of Education and Practice, 4(16), 172-180.

Ary, D., Jacobs, L. C., \& Sorenson, C. (2010). Introduction to Research in Education. New York, NY: Wadsworth Cengage Learning.

Ballout, H. I. (2007). Career success: The effects of human capital, person-environment fit and organizational support. Journal of Managerial Psychology, 22, 741-765. doi:10.1108/02683940710837705

Becker, G. S. (1964). Human capital: A theoretical and empirical analysis with special reference to education. Chicago, IL: University of Chicago Press.

Berntson, E., Sverke, M., \& Marklund, S. (2006). Predicting perceived employability: Human capital or labour market opportunities? Economic and Industrial Democracy, 27, 223244. doi:10.1177/0143831X06063098

Bimrose, J., \& Hearne, L. (2012). Resilience and career adaptability: Qualitative studies of adult career Counselling. Journal of Vocational Behaviour, 81(3), 338-344. doi:10.1016/i.jvb.2012.08.002

British Council of Nigeria. (2014). Can higher education solve Africa's job crisis? Understanding graduate employability in Sub-Saharan Africa. London: Accessed $11 / 05 / 2018$, https://www.britishcouncil.org/sites/default/files/graduate_employability_in_ssa_final -web.pdf

Creswell, J. W. (2007). Qualitative inquiry and research design: Choosing among the Approaches (2nd ed). Thousand Oaks, CA: SAGE Publications.

Christie, F. (2016). Careers guidance and social mobility in UK higher education: practitioner perspectives. British Journal of Guidance \& Counselling, 44(1), 72-85. doi: 10.1080/03069885.2015.1017551

Collet, C., Hine, D. \& du Plessis, K. (2015). Employability skills: Perspectives from a knowledge intensive industry. Education + Training, 57 (5), 532-559. doi: 10.1108/ET$\underline{07-2014-0076}$

Efeturi, A. L. (2015). The need for more guidance and counselling services in Nigeria schools. The Nigerian Voice. Available at https://www.thenigerianvoice.com/news/187103/theneed-for-more-guidance-and-counseling-services-in-nigeri.html

Emeh, I. E., Nwanguma, E. O., \& Abaroh, J. J. (2012). Engaging youth unemployment in Nigeria with youth development and empowerment programmes: The Lagos state in focus. Interdisciplinary Journal of Contemporary Research in Business, 4, 1125-1141 
Eyo, M. B., Joshua, A. M., \& Esuong, A. E, (2010). Attitude of secondary school students towards guidance and counseling services in Cross River State. Journal of Counselling, $3(1), 87-99$.

Eze, C. P. (2013). Empowering the youth through technical and vocational education: A panacea for sustainable national development. Unizik Orient Journal of Education, 7, $59-64$.

Federal Republic of Nigeria (2013). National policy on education. Abuja. NERDC Press.

Floersch, J., Longhofer, J. L., Kranke, D. \& Townsend, L. (2010). Integrating thematic, grounded theory and narrative analysis: A case study of adolescent psychotropic treatment. Qualitative Social Work: Research \& Practice, 9 (3), 407-25.

Foskett, N. (2004). Information, advice and guidance and young people's participation decisions. Nuffield Review of Education and Training Working Paper 25.http://www.nuffield14-19review.org.uk/files/documents136-1.pdf. [Accessed: 11.6.2018]

Gibbert, M., Ruigrok, W., \& Wicki, B. (2008). What passes as a rigorous case study? Strategic Management Journal, 29 (13), 1465-1474. doi:10.1002/smj.722

Glaeser, E. I., Ponzetto, G. A. M. \& Shleifer, A. (2007). Why does democracy need education? Journal of Economic Growth, 12, 77-99. doi:10.1007/s10887-007-9015-1

Guest, G., Bunce, A., \& Johnson, L. (2006). How many interviews are enough? An experiment with data saturation and variability. Field Methods, 18, 59-82. doi: $10.1177 / 1525822$ X05279903

Hack-Polay, D., Igwe, P. A. \& Okolie, U. C. (2020). Room for improvement: A study of overconfidence in numerical skills among British graduates. Industry and Higher Education, 34 (1), 50-61. doi:10.1177/0950422219864004

Hooley, T., \& Dodd, V. (2015). The economic benefits of career guidance. Career in England. Available atwww.careersengland.org.uk Accessed 10/05/2018

Hunkin, E. (2018). Whose quality? The (Mis) uses of quality reform in early childhood and education policy. Journal of Education Policy, 33 (4), 443-456. doi: $10.1080 / 02680939.2017 .1352032$

Iruonagbe, C. T., Imhonopi, D. \& Egharevba, M. E. (2015). Higher education in Nigeria and the emergence of private universities. International Journal of Education and Research, 3(2), 49-64

Lingard, L. \& Kennedy T. J. (2010). Qualitative research methods in medical education. In Swanwick T, editor. Understanding medical education: evidence, theory and practice. West Sussex: Wiley-Blackwell; p. 323-335

Lunenburg, F. C., (2010). School guidance and counselling services. Schooling, 1 (1), 1-9.

Marginson, S. (2019). Limitations of human capital theory. Studies in Higher Education, 44(2), 287-301. doi: 10.1080/03075079.2017.1359823

McGregor, R. \& Park, M.S-A. (2019). Towards a deconstructed curriculum: Rethinking higher education in the global North. Teaching in Higher Education, 24(3), 332-345. doi: $10.1080 / 13562517.2019 .1566221$

McKenzie, S., Coldwell-Neilson, J., \& Palmer, S. (2017). Informing the career development of IT students by understanding their career aspirations and skill development action plans. Australian Journal of Career Development, 26(1), 1423. doi:10.1177/1038416217697972

Mogbo I. N., Obumneke-Okeke I. M \& Anyachebelu, F.E. (2011). Implementation of guidance and counselling services in Nigerian schools. Journal of Emerging Trends in Educational Research and Policy Studies, 2(5), 361-264.

Modo, F., Sanni, K., Uwah, C. \& Mogbo, I. (2013). Guidance and counselling services in secondary school as coping strategy for improved academic performance of students 
Facilitating Career Development in TVET Graduates

in Akwa Ibom State, Nigeria. Research on Humanities and Social Sciences, 3(4), 4347.

Mohammed, D.S. \& Ismail, S. (2014). Employability skills definitions and framework for tvet graduates' employment. Proceedings of the 1st TVEIS International Seminar on Technical and Vocational Education, UTM, Johor Bahru, Malaysia, August 25-26, pp. 682-694.

Mohammed, D.S. \& Ismail, S. (2015). Employability skills in TVET curriculum in Nigeria Federal Universities of Technology. Procedia - Social and Behavioral Sciences, 204, 73-80. doi: 10.1016/j.sbspro.2015.08.111

Musa, A. (2010). Improved apprenticeship system as means for achieving the millennium development goals in Nigeria. Nigeria Journal of Technology Education, 1 (1), $105-$ 110.

Mutie, E. K., \& Ndambuki, P. (2011). Guidance and Counselling in Schools and Colleges. Nairobi. Oxford University Press.

Nwankwo, F. C., Obeta, C. O., \& Nwaogbe, V. K. (2013). Integrating technical and vocational education in youth empowerment programmes: An approach to nation building and job creation in Nigeria. Journal of Education and Practice, 4 (16), 87-90

Ojimba, D. P. (2012). Vocational and technical education in Nigeria: Issues, problems and prospects dimensions. Journal of Education and Social Research, 2(9), 75-83

Okolie U. C. (2014). Management of woodwork workshop in tertiary institutions in Nigeria: An analytical study. Malaysian Online Journal of Educational Management, 2(1), 2036.

Okolie, U. C., Igwe, P. A., \& Elom, E. N. (2019). Improving graduate outcomes for technical colleges in Nigeria. Australian Journal of Career Development, 28(1), 21-30. doi: 10.1177/1038416218772189

Okolie, U. C., Nwosu, H. E. \& Mlanga, S. (2019). Graduate employability: How the higher education institutions can meet the demand of the labour market. Higher Education, Skills and Work-Based Learning, 9(4), 620-636. doi:10.1108/HESWBL-09-2018-0089

Okunuga, R. O. \& Ajeyalemi, D. (2018). Relationship between knowledge and skills in the Nigerian undergraduate chemistry curriculum and graduate employability in chemicalbased industries. Industry and Higher Education, 32(3), 183-191. doi: $10.1177 / 0950422218766913$

Oluwale, B.A., Jegede, O. O., \& Olamade, O.O. (2013). Technical and vocational skills depletion in Nigeria and the need for policy intervention. International Journal of Vocational and Technical Education, 5(6), 100 -109

Organisation for Economic Co-operation and Development (2019). About career information and guidance. Retrieved from http://www.oecd.org/education/innovationeducation/aboutcareerinformationandguidance.htm

Page, S., Trudgett, M. \& Bodkin-Andrews, G. (2018). Creating a degree-focused pedagogical framework to guide Indigenous graduate attribute curriculum development. Higher Education, 78(1), 1-15. doi:10.1007/s10734-018-0324-4

Patton, M. Q. (2002). Qualitative research and evaluation methods. Thousand Oaks, CA. Sage Publications.

Pitan, O. S. (2017). Graduate employees' generic skills and training needs. Higher Education, Skills and Work-Based Learning, 7(3), 290-303. doi:10.1108/HESWBL-04-2017-0026

Pitan, O. S. \& Atiku, O. S. (2017). Structural determinants of students' employability: Influence of career guidance activities. South African Journal of Education, 37(4), 113. doi:10.15700/saje.v37n4a1424 
Pitan, O. S. (2016). Employability development opportunities (EDOs) as measures of students' enhanced employability. Higher Education, Skills and Work-Based Learning, 6 (3), 288-304. doi:10.1108/HESWBL-05-2016-0024

Rawkins, C. (2018). A global overview of TVET teaching and training: Current issues, trends and recommendations. Report submitted to the 13th Session of the Joint ILO-UNESCO Committee of Experts on the Application of the Recommendations concerning Teaching Personnel (CEART). Geneva.

Reddya, G.C. \& Rajaram, N.J. (2015). Career aspirations and background of students opting for fashion education courses in India. Procedia - Social and Behavioral Sciences, 176; 952-960

Savickas, M. L. (2011). Career counselling. Washington, DC: American Psychological Association.

Solem, M., Kollasch, A. \& Lee, J. (2013). Career goals, pathways and competencies of geography graduate students in the USA. Journal of Geography in Higher Education, 37 (1), 92-116. doi:10.1080/03098265.2012.729563

Schultz, T. W. (1959). Investment in man: An economist's view. Social Service Review, 33(2), $109-117$.

UNESCO (2015). Recommendation Concerning Technical and Vocational Education and Training (TVET), Paris.

UNESCO (2012). Transforming TVET: Building skills for work and life. General report, Third International Congress on Technical and Vocational Education and Training, Shanghai. China.

Usman, A. N. \& Tyabo, A. (2013). Revitalizing technical and vocational education (TVET) for youth empowerment and sustainable development. Journal of Educational and Social Research, 3(4),149-154.

World Bank (2019). The World Bank in Nigeria. http://www.worldbank.org/en/country/nigeria/overview 